\title{
sciendo
}

\section{CONCEPTUAL FRAMEWORK AND EMPIRICAL METHODOLOGY FOR MEASURING MULTIDIMENSIONAL JUDICIAL IDEOLOGY}

\author{
Matej Avbelj ${ }^{1}$, Janez Šušteršič ${ }^{2}$
}

\begin{abstract}
The article presents a conceptual framework and empirical methodology of an on-going research on the role of ideology in the decisions of the Slovenian Constitution Court. The literature review demonstrates that research on judicial ideology in the courts of European countries and international courts is still rare. This can be explained by conceptual, methodological and empirical challenges posed by this type of research. The article hence advances a conceptual framework which is, contra to the mainstream theoretical approach in the field, based on a multidimensional conception of ideology that is empirically operationalised along the economic, social and authoritarian dimensions with five possible ideological positions on each dimension. By applying the newly developed methodology to a sample of Court's decisions, it is demonstrated that this methodological approach is able to account for ideological differences between judges. This confirms that (judges') ideology is a complex multidimensional set of values and convictions that cannot be reduced to simply equating ideology with (possible) political affiliations.
\end{abstract}

\section{Keywords}

Judicial Ideology, Multidimensional Methodology, Constitutional Court of the Republic of Slovenia, Objectivist Concept of Law

\section{Introduction}

How ideological are our courts? This is a question that is still relatively rarely raised, but when it is posed, it spurs controversies and is in many, not infrequently very influential, legal circles considered as nothing short of a provocation. In some jurisdictions, including in Slovenia, which this article will rely upon as source of its empirical study, such a question can even be regarded as a means of delegitimizing the judiciary, as a (political) instrument of encroachment on the difficultly won judicial impartiality and independence. However, the present article is in service of none of the said negative objectives. To the contrary,

\footnotetext{
${ }^{1}$ Nova Univerza, Slovenia, Žanova ulica 3, 4000 Kranj, Slovenia. E-mail: Avbelj@gmail.com.

${ }^{2}$ Re-forma d.o.o. Ljubljana, Slovenia. E-mail: sustersic.janez@gmail.com.
} 
its purpose is to contribute to judicial independence and impartiality and to strengthen the role of the judiciary in the system based on the rule of law. This ambition requires asking the question of judicial ideology rather than shying away from it. The fact that a particular epistemic community reacts forcefully, at times even emotionally, to certain questions speaks in favor of their importance and therefore calls for more rather than less research attention.

This conclusion is strengthened further when an important question, such as that of judicial ideology, has received relatively little attention. As section two of the paper will demonstrate, other than in the common law countries, in particular in the USA, the research in judicial ideology is still at an early stage. Furthermore, as the continuation of the discussion in section three of the article will show, there remain many jurisdictions on the national and transnational level, which deliberately prevent the expression of ideology by the courts. It is the central conceptual contribution of this paper to argue, in section four, that different practical approaches to expressing or hiding judicial ideology as well as the attitudes to the very question of judicial ideology derive from three different understandings of the concept of law. These are: the objectivist, the subjectivist and the discursive conception of law. Having critically examined each of them, the paper opts for a discursive conception of law, which is the most conceptually and normatively persuasive approach to the actual legal practices in modern legal systems and which is, furthermore, the only conception of law, which provides a conceptual space for judicial ideology.

But even when researchers embrace a conception of law that allows for existence and importance of judicial ideology, they still need to address the challenge of whether the empirical methodologies developed for measurement of judges' ideology in the context of the USA may be applied to courts in continental Europe. The prevailing approach in the current empirical research, which is to distribute the judges along a single ideological dimension, is attractive for its relative clarity and simplicity, but it also fits best with the American political ideological space, which has been for decades quite clearly divided in binary terms between the liberals and the conservatives. A bipolar political space also allows the researchers to use the nomination by a Republican or a Democratic President as an indicator of a judge's expected ideological position. Such an openly bipolar political space is, however, specific to America and it does not exist to the same extent elsewhere, especially not in the continental Europe, where parliaments and government majorities comprise several ideologically diverse political parties which cannot easily be ordered along a single left-right dimension. In such contexts, the unidimensional approach to judicial ideology has less conceptual validity. There is also no straightforward way of using the nomination process as a proxy for ideology when judges are elected with votes from several parliamentary parties.

The main contribution of this paper is to develop a conceptual and empirical methodology for assessing Constitutional Court judges' ideology in countries which are characterized by a complex political and ideological space, and to demonstrate how the methodology could be applied for an empirical analysis. Our approach is thus strictly a deductive one; we believe that before venturing into empirical research, one must develop sound definitions of concepts that are to be measured and dispose of reliable primary data corresponding 
to these definitions. The choice of a deductive approach presents us with a three-fold challenge: conceptual, methodological and empirical. The conceptual challenge involves developing a conceptual framework which is based on an understanding of law that allows for existence of judicial ideology and defines ideology in terms that do not carry the common negative connotations and could thus be acceptable for most of the profession. After reviewing the existing empirical literature in section two, we develop such a conceptual framework in sections three and four of the paper, providing our own generous and inclusive interpretation of judicial ideology.

This conceptual choice enables us to move to the methodological challenge faced by the research in judicial ideology. Here the pestering dilemma has been whether to measure judicial ideology in unidimensional or multidimensional terms. In section five of the paper we propose, contra to the leading literature in the field, a multidimensional methodological approach to judicial ideology. The three dimensions (economic, social and authoritarian) are defined as clearly distinct from each other and not reducible onto a single bipolar dimension, and a methodology for identifying ideological position of the Court and judges along the three dimensions is developed.

Finally, the empirical challenge is addressed in section six, which applies the methodology to the jurisprudence of the Slovenian Constitutional Court. The latter, due to its openness and transparency, lends itself as an excellent case study for measuring judicial ideology. Unlike most of the literature, which estimates the underlying ideology from judges' voting history or proxies it by their nominating parties and other secondary information, our empirical approach is based on directly observing expressions of ideology in the Court's justifications of its decisions and in the concurring and dissenting separate opinions of individual judges. The result of our empirical work is a database of ideological positions the judges and the Court took on each of the decisions in the sample. This database is intended as a source for further empirical research which could address a range of questions about judicial behaviour and ideology.

\section{Researching Ideology in National and Transnational Courts}

A comparative review of the leading literature on judicial ideology shows that, with the exception of the US, legal scholarly focus on the ideology in courts is only at the initial stage of its development. There are significant differences between the US, where the empirical approach to law, which is required when examining the role of judicial ideology, has been well-developed already for a while, and Europe and other parts of the world where it only started emerging in the 1990s (Garoupa, 2010; Garoupa, 2016). An even closer look at the literature reveals a fundamental division along the line between the Anglo-Saxon common law systems and the European continental system with its derivations around the world. As Nuno Garoupa demonstrates (ibid.), the basic difference runs along the different type of courts. Courts in common law systems, particularly in the US, but also in the UK, Canada and Australia, have been subject to thorough empirical research about the influence of ideology on judicial decisions, while the opposite is true for analyses of the so-called Kelsenian courts in a centralized systems of judicial review, topped by the constitutional court (Ginsburg, 2011). 
In the US, extensive theoretical and empirical research has been conducted about ideology in the courts, its influence on court decisions and different approaches to measure this influence (Bailey, 2016; Bailey, Maltzman 2011; Spitzer, Talley, 2013; Klein, Lindquist, 2012; Epstein, Landes, Posner, 2013; Fischman, Law, 2009). Modelled on the research in the US, similar research started emerging in Canada (Ostberg, Wetstein, 2007; Songer, Johnson, Ostberg, Wetstein, 2012; Wetstein, Ostberg, Songer, Johnson, 2009; Alarie, Green, 2008). Quite extensive research, also modelled on the American example, can also be found in relation to the work of British courts (Blanes i Vidal, Leaver, 2011, 2013; Hanretty, 2012a; Iaryczower, Katz, 2016). Already in the early 1980s, David Robertson (1982) empirically studied the influence of ideology on decisions in the House of Lords, and later developed an elaborated theoretical notion of judges as political theorists (Robertson, 2010). Similar research is less frequent in Australia (Narayan, Smyth, 2007), and even more of a rarity in Europe. Garoupa thus lists (Garoupa, 2016) only a handful of authors conducting empirical research on the work of courts in Germany (Vanberg, 2005; Hönnige, 2009), Belgium (Dalla Pellegrina, De Mot, Faure, Garoupa, 2016), Bulgaria (Hanretty, 2014), Poland (Kantorowicz, Garoupa, 2016) and Norway (Grendstad, Shaffer, Waltenburg, 2015). On the other hand, there has been quite some research in this area since 2000 in a few countries, first in France (Brouard 2010; Franck, 2009; Espinosa, 2015), Spain (Magalhães, 2002; Garoupa, Gómez-Pomar, Grembi, 2013; Hanretty 2012b; Dalla Pellegrina, Garoupa, Gómez-Pomar, 2014) and especially Italy (Volcansek, 2000; Santoni, Zucchini, 2003; Padovano, 2009; Fiorino, Padovano, Sgarra, 2007; Garoupa, Grembi, 2015), as well as in Israel (Shachar, Gross, Harris, 1997; Winshall-Margel, 2011; Eisenberg, Fisher, Rosen-Zvi, 2013).

The reviewed empirical research pursued a diverse set of objectives: determining the level of independence of individual judges and courts; determining the influence of the (political) appointment procedure on judges' decisions; determining the decisionmaking dynamics in the courts with respect to the composition of their senates, or the influence of the presiding justice and/or judge-rapporteur. Empirical research thus analyses the sociological, psychological, situational and other circumstances affecting judges' decision-making, but only few analyses focus precisely on determining the worldview, e.g. ideological orientation of judges and measuring its impact on the decisions they make. Although the example of the US has led to more empirical analyses also in Europe and other parts of the world since 2000, their number remains low.

This conclusion is accentuated further when extended to the research in transnational judiciary, e.g. to the courts working beyond the state either on the international, regional or supranational plane. The research is rather limited and to the extent it does exist, it has not focused on the question of judicial ideology stricto sensu, but rather on the judges' actual capacity to carry out their judicial role in an independent and impartial manner. This is, in particular, true of the scholarship focusing on the International Court of Justice (ICJ), which has mostly examined to what an extent nationally appointed judges as members of the international court continue to exhibit their national biases (Posner, de Figeuiredo, 2004). 
Similar approach has also been adopted with regard to the Court of Justice of the European Union (ECJ). Here too the researchers have mostly measured the impact of the member states on judges' decision-making, focusing on the judges' choice to either support more integration (Europhilia) on the one end or the interests of member states (Euroscepticism) on the other (Malecki 2012, Carrubba, Gabel and Hankla, 2008). However, in contrast with the ICJ where judges are permitted to publish their dissenting opinions, at the ECJ they are not. This has made studies of individual judge's positions, let alone of their ideological views, much more cumbersome. Malecki (2012) has thus, for example, tried to identify the individual judges' policy preferences on the basis of the analysis of the decisions of chambers composed of different judges.

On the other hand, the research on ECtHR has gone somewhat deeper and has moved beyond the questions of independence and impartiality, which are usually related to the nationality of a judge and his or her relationship to the appointing state. Also due to a different nature of the ECtHR which, as a human rights court, does not (typically) rule on the international disputes between states, the question of bias here, unlike in the case of the ICJ, has approached more closely the issue of judicial ideology, querying into the individual judge's normative orientation in favor of human rights or state interests (Toplak, 2016). The research on ECtHR has demonstrated that legal culture and geopolitics are not important sources of bias among its judges. On the other hand, there is much more evidence that, not unlike the national judges, the ECtHR judges too are "political actors in the sense that they have policy preferences that shape their choices" (Voeten 2008). This, as Voeten has observed, permits relying on methods and theories developed for the study of national judiciary, also in the transnational realm. Dunoff and Pollack (2015), writing about the domestic judicial dissent also as a means of expression of diverse judicial ideologies, concur. While they emphasize that "domestic frameworks cannot simply be pulled off the shelf and applied uncritically to international courts and judges", they nevertheless believe into utility of the research on domestic courts on the international plane too.

\section{Conceiving of, Expressing and Observing Judicial Ideology}

As stressed in the introduction, despite the empirical literature, the very notion of judicial ideology is still a controversial issue in legal scholarship. While ideology has meant different things to different authors and continues to divide opinions sharply (Fischman, 2009), it normally comes with a negative connotation, associated with politics stricto sensu, that is with the political conflicts for power that are conducted in an ideological manner or for ideological purposes, or both. Within this understanding, ideology is conceived of as a means of doing (party) politics in two ways that approximate closely what Mannheim (1966) has described as cant mentality or purposeful lie. According to the former, politicians, their supporters and pundits "distort and misrepresent the reality for certain pragmatic or vital-emotional reasons". (ibid.) According to the latter, the powerwielding subjects engage in "purposeful deception of others" (ibid). In either way, this deeply negative, ideological political practice is in function of the preservation of the dominant class, of its interests that no longer correspond to the actual reality out there (ibid.). 
The negative connotation of ideology, coupled with a specific understanding of the law, which we discuss in the next section, has led many jurisdictions to supress direct expressions of judges' ideological positions. This poses a challenge for an empirical scientist who would like to observe judicial ideology directly, as expressed through the judges' actual voting behaviour and their writing, both collectively in justifications of decision and individually in the form of either concurring or dissenting opinions. It is there, in their separate opinions, that judges present their specific individual takes on the case and in so doing, intentionally or not, also reveal their ideological perspective on the questions raised. In the absence of separate opinions, when the court rules per curiam, not even listing judges' names, let alone those who have voted in favor and against the ruling, it is impossible to determine the individual judge's legal and ideological position on the basis of observation of a judge's actual conduct. ${ }^{3}$

However, the practice of judges writing separately varies around the world. As noted by Ginsburg, roughly three distinct historical models of (in)existence of separate opinions can be distinguished (Ginsburg, 2010). In the British system, there is no opinion of the court and each judge is writing separately. The US system, which proceeded from the British model, has since developed autonomously so that there is an opinion of the court, while the judges are entitled to write separately. By contrast, the continental European system has traditionally not allowed for separate opinions (ibid). In the most conservative manner, epitomized by the judiciary in France, the courts are conceived of and function as faceless, unanimous units (Bricker, 2017), whose rulings are drafted in cryptic language and the individual judges are entirely subsumed under the institution of the court, so that their opinions are blended into what the law as such is found to require. However, since the 1970s, with the German Federal Constitutional Court acting as an avant-garde, the continental European model has undergone significant internal differentiation with respect to separate opinions, to the extent that the historically relatively clean line between common law and civil law jurisdictions has been more or less blurred (European Parliament, 2012). The French model today thus increasingly occupies an extreme position. A study by the European Parliament has found that today only seven national jurisdictions in the EU do not allow for separate opinions. ${ }^{4}$ In all other EU national jurisdictions, the judges at the constitutional courts, but sometimes also in the ordinary judiciary, are permitted to write separately. A similar trend has been present among transnational courts, where most of them practice separate opinions (Dunoff, Pollack, 2015), the ECJ being a notable exception.

While the trend has thus clearly been in favor of separate opinions, several jurisdictions, especially the ECJ (Azizi, 2011), as well as scholars insist that there remain potent arguments against them. Two central legal values in particular have been promoted as an argument against separate opinions: legal certainty and judicial independence. Bricker

\footnotetext{
${ }^{3}$ To compensate for this, the literature has developed other methodological approaches to measure judicial ideology, not based on observation of judge's actual behaviour. The two other, most frequently used approaches have been the bypolar and agnostic coding methods and the use of the so-called "proxy variables" (for an overview, see Fischman, Law, 2009).

${ }^{4}$ Belgium, France, Italy, Luxembourg, Malta, the Netherlands and Austria.
} 
thus observes that the traditional absence of dissenting opinions, judicial secrecy, attempts at creating a faceless, unanimous courts in continental Europe, in the so called civil law legal systems, has been motivated with an ambition of preserving legal certainty as one of the cornerstone values of the law (Bricker, 2017). Separate opinions, in particular the dissenting ones, would send a message that the law is not settled, that the question of the right legal answer is contested, which could, taken together, result in less persuasive and therefore also less legitimate judicial rulings. The authority of the courts would thereby be affected, which might result in the judicial rulings not being followed uniformly or even not being followed at all. In this way, the integrity of the legal system as a whole would be undermined. To prevent that, however, not just the authority of the courts has to be preserved, but also the latter's independence. As described by Dunoff and Pollack (2015), limiting dissent in some continental European jurisdictions has been presented as being in service of judicial independence (ibid.). Judges writing separately may be exposed to retaliation or award by the political branch or the electorate (ibid.), especially when they are not tenured and face re-election. Finally, it has been submitted that separate opinions increase the likelihood of damaging the collegiality among judges, if and when their disagreements are publicly disclosed (ibid.). These and other arguments against separate opinions and the fact of diverging practices around the world has led Ginsburg to conclude that: "what is right for one system and society may not be right for another" (Ginsburg, 2010).

However, it is an unobjectionable fact that everywhere around the globe judges are still human beings, made of flesh and blood, in possession of, typically, well developed and well thought-through worldviews with which they, in a subjective manner, as persons, approach and take part in their judicial roles. Laws that judges are called upon to apply in concrete cases always require construction. Judging thus involves judge's personality as a whole: her professional dimension as a knowledgeable lawyer as well as the other dimension of an accomplished ethical person with an established worldview. The meaning of law is thus socially constructed. It is not pre-given, rather it is a product of law-making activities of authorized individuals: legislators, executives and judges. The meaning of law is thus always determined inter-subjectively and it is therefore never settled for good. Reasonable people, even those with sharpest minds and highest integrity, have reasonably disagreed about the meaning of law in general, but especially so in hard cases. For judges "have preferences and vote on case outcomes consistent with those preferences" (Malecki, 2009). This has been and remains a universal fact, one that cannot be denied by falling back on the particularist conclusion à la Ginsburg, nor can it be persuasively hidden in the name of preserving legal certainty, independence, legitimacy, authority and collegiality of judges. What is more, this fact should not be hidden, ${ }^{5}$ as it is by way of hiding it - by way of denying something that has always been part and parcel of law and judicial law-making - that the values of legal certainty, independence, legitimacy and authority of courts are actually threatened. That certain jurisdictions and scholars continue to downplay this fact, or even deny it - and therefore also negate any value of the existence, measuring and

\footnotetext{
${ }^{5}$ Malecki (2012) argues that institutional independence, in whose name the ECJ is one of the most non-transparent judicial institutions in Europe, provides a cover for the Court and its judges that do not share uniform preferences.
} 
importance of judicial ideology - does not (necessarily) mean that they are doing that out of some fraudulent motive or for some negative purpose. Most likely they are just sticking to a different concept of law. The one that provides no room for individual judge's contribution to law and hence also excludes the relevance of raising a question of judge's ideological profile in the first place.

\section{Judicial Ideology and the Three Conceptions of Law}

In light of the preceding discussion this section argues that legal systems' and scholars' differing attitudes to the questions of judges writing separately as one of the means of expressing and, therefore, observing judicial ideology $y^{6}$ can be explained by the fact that they are based on three different conceptions of law. These are the objectivist conception; the discursive conception and the subjectivist conception of law. The first conceives of law as an objectivist and positivist system, which draws its authority from its form. The second comprehends law as an argumentative and discursive practice, whereby the authority of law and, particularly of the courts, is based on how persuasive the arguments underlying the rulings are. Whereas the third conception sees law as entirely subjective, as an outcome of political, even purely personal preferences of judges dressing up as law, as legal language. In what follows, each of the three conceptions is described in some more detail.

Law as an objectivist and positivist system draws its authority from its form. According to this conception, court rulings need to be respected because they are made by institutions consisting exclusively of legal experts who have no preference in terms of values, or their own values in no way affect their rulings. This is also reflected in the traditional appearance of the judiciary: judges wear special robes and in some cases wigs to hide their faces from the public, and show that they are different from ordinary people, that they have authority and are consecrated for making judicial decisions. The principal author of this approach to law - at least in theory if not necessarily in practice - was Hans Kelsen (1960). According to his theoretical views, law is a system of hierarchically organised legal rules in which higher-ranking rules determine the content and procedure for the creation of lower-ranking legal norms. The highest formal legal act is the constitution, which determines all other, lower-ranking legal acts and it is itself not derived from any formal legal act, but rather a meta-norm that is the logical precondition for the entire legal system.

Law thus creates and recreates itself and is completely separate from other normative systems: morality, religion and politics. This is the essence of its purity. Law is pure science with no other social and value-related components, so these cannot be used to judge its (in)validity or the (in)appropriateness of legal regulations. Morality, let alone politics, is outside the realm of legal science (Raz 2009). Therefore it also cannot affect lawyers as such. Lawyers are seen as objective and capable of searching for and finding the material truth because, in their core, they are dedicated to pure law and cannot be

\footnotetext{
${ }^{6}$ Bricker's (2017) research demonstrates that the number of dissenting opinion in constitutional courts grows in cases brought with political elements (brought by members of parliament); complex cases and by judges with an academic background who are not concerned just by a concrete dispute resolution, but involve their own theories in judicial decision-making, e.g. are more reflexive and have a more in-depth understanding of a value and policy based problematique surrounding a particular case.
} 
influenced by morality and politics. Therefore, also the scope of law, according to Kelsen, is very narrow, and definitely strictly separate from politics and other social, value and worldview-related elements. The role of courts pursuant to the objectivist conception of law is to determine the material truth based on legal norms with an objective meaning. Any sign that judges have based their decision on their own beliefs is therefore seen as a deviation from the legal ideal and a reason for criticism. The same logic implies that court rulings, supposedly reflecting objectively found material facts, should not be subject to public or political debate. In short, in the objectivist conception of law there is no room for judicial ideology.

A different approach comes from the understanding of law as an argumentative and discursive practice. This discursive conception of law is embodied on the global level in Dworkin's approach to law as an interpretative practice (Dworkin, 1986), while the biggest contribution in the European context comes from Alexy's (2009) legal theory and the philosophical, sociological and political-science approach of Habermas (1996). Dworkin (1986) has been stressing since the 1980s that law - and all legal decisions essentially reflect the political morality of a particular political community. Contrary to what Dworkin's contemporary H.L.A. Hart (1961) claimed - at least at first - law is not only a comprehensive and hermetically sealed system of legal rules and principles. Through decision makers in the society, particularly judges, the values and worldviews of these decision makers always penetrate the system. Therefore, their task is to present persuasive arguments for their decisions in the light of prior legal decisions and, what is particularly important, in the light of their best understanding of their community (Dworkin, 2013). Law and morality - regarded as two separate normative worlds by many objectivist and positivist approaches to law, especially in the works of Hans Kelsen, Joseph Raz (2009) and others - are seen by Dworkin as inextricably bound and mutually enriching, and a toneddown version of this view is even supported by some legal positivists (e.g. MacCormick, 2007).

Robert Alexy (2009) uses a similar basis for arguing that rights are principles, and principles are demands for optimisation. As such, rights are always - but especially when different rights clash - subject to a proportionality test, which is again affected by the decision maker's value-based worldview, both when determining whether an objective is constitutionally acceptable and even more when determining whether the selected means is appropriate, necessary and proportional. Jürgen Habermas (1998) contributes a more philosophical, sociological and political science-related perspective to the discursive approach to law, particularly in his treatises on the need for legitimacy in law, which he finds in the greatest possible inclusion of different people in the discussion, which they, again, inevitably enter with their own different worldviews.

From the perspective of the discursive conception of law, the authority of law and particularly of the courts is therefore based on how convincing the arguments underlying their decisions are. It is thus not about the form or creating an appearance - with wigs or by stressing that not everyone can wear a judge's robe -, but rather about content and arguments that will convince the parties involved and the general public why it was right that one particular party lost and the other one won (Rosenfeld, 2006). If law is an 
argumentative and discursive practice and court senates comprise several different judges, it is clear that these judges will often support different legal opinions and provide different arguments for them. This is not only self-evident but it is right as well, because only the existence of different views can guarantee a fair and objective trial, objective in the sense of ensuring the broadest possible intersubjectivity.

Law as a discursive and argumentative practice, limited by specific legal and institutional rules of legal discourse (Alexy, Adler, MacCormick, 2009), moves the focus from the legal form to the legal subject - the lawyer, who makes the decision. Between a legal regulation and a practical legal issue, there is always a person (Pavčnik, 2013) - the lawyer, who must always make the decision by him or herself and must also take a responsibility for it. Law is therefore not something objective, but a product of lawyers, who are people made of flesh and blood, and who have a well-defined ideological profile, as is expected of an adult, mature person and a legal expert. The discursive conception of law thus acknowledges that judicial ideology is an inevitable part of judge's decision-making. As such, it must not only be recognized, but it must be made transparent, measured and researched. In this way it is ensured that judicial ideology, its role, remains within the boundaries prescribed by the legal discourse, so that it is the judicial ideology which is in function of the law, rather than the law being purely a product of (judicial) ideology.

The latter is essentially what the subjectivist conception of law stands for. The subjectivist conception grows out of the movement that flourished in the US especially in the 1920s and 1930s and has since been known as legal realism (Tamanaha, 2009). Developed against the objectivist conception of law, taking the form of legal formalism (Leiter, 2010), the US legal realists, especially Oliver Wendell Holmes, Roscoe Pound and Benjamin Cardozo, stressed that law always contains parts that are undefined, that it is full of contradictions and exceptions, and that almost every legal rule or principle allows for several explanations (ibid.). However, legal realism was not limited to the US. It also emerged in Europe, where Swedish and Danish philosophers Hägerström and Ross established the so-called Scandinavian legal realism (Bjarup, 2005). The American and the Scandinavian legal realism pursue different goals because the objects of their criticism are different. As Alexander clearly shows, the former stresses that law is inevitably political, while the latter rejects an objectivist nature of law as something metaphysical and the idea that legal theory is above democratic political decision making (Alexander, 2002). While both approaches are critical of the notion of law as a pure legal science, completely independent from the people deciding on concrete cases, the American brand of legal realism goes further by concluding that judges rule simply on the basis of their personal preferences, and then choose and adapt their legal arguments accordingly (Tamanaha, 2009). In this way the law is entirely subjective. ${ }^{7}$ All that matters is judicial ideology. The role of law is purely instrumentalist. It merely provides a form for articulating particular ideological goals by institutional actors in power, in our case judges. In the most extreme version of the subjectivist conception of law it is even argued that judicial decisions are entirely random, admittedly packed in a legal form, but they have more to do with what judges

\footnotetext{
${ }^{7}$ In political science this subjectivist approach to law has also been captured through the language of attitudinal model of law or through the behavioralist approaches to law.
} 
ate for breakfast and how long and well they slept (Kozinski, 1993) than with the alleged judicial expertise and constraints inherent to the legal discourse. As judicial ideology is thus pervasive in the subjectivist conception of law, it is everywhere, it consequently makes little sense to research it and to measure its influence on legal decision of judges, when these decisions are, in effect, not legal at all (but purely ideological).

\section{Multidimensional Definition of Judicial Ideology}

In the preceding sections we have analyzed to what extent the question of judicial ideology has been addressed in the literature on domestic and transnational judicial decisionmaking, how judicial ideology is allowed to be expressed in different legal systems and how that goes back to the differences between the three basic conceptions of law. We have explained how the adherence to the objectivist conception of law may lead legal scholars and practitioners to deny the very existence of judicial ideology. On the other end, a purely subjectivist understanding of judicial decision-making opens the door widely for an influence of ideology and other subjective preferences, but is not able to free the notion of ideology from its negative connotation.

In this article, ideology is understood in a more neutral way, corresponding to the discursive conception of law. Ideology is synonymous with a worldview of a person, a judge in our case. Accordingly, writing about judicial ideology and defining a judge's ideological profile means addressing a comprehensive system of values, beliefs and views through which, as through a normatively colored lens, a person observes, sees and, when taking action, partakes in creating the social world around herself. Judicial ideology as used in this article therefore covers political views in the broadest sense of the term: politics as everything related to public matters, but not in the narrow party politics sense. ${ }^{8}$ Precisely because ideology is conceptually an important, but not an overriding element of judicial decision making, it needs to be acknowledged and researched in order to understand its nature and the implications for judicial decisions.

Having defined our understanding of judicial ideology, we now move further to the methodological challenge of whether it suffices to approach judicial ideology methodologically in unidimensional, binary terms (left/right; liberal/conservative) or is it necessary to go beyond it and opt for a multidimensional methodological approach.

As noted by Bailey, the one-dimensional model for measuring judicial ideology is prevalent in the US. He cites three basic reasons for that: convenience, actually existing unidimensionality and normative attractiveness (Bailey, 2016). Accordingly, the unidimensional approach is neat and simple; the ideology eventually indeed boils down to a single dimension and, finally, it is often desirable, for the purpose of transparency and greater intelligibility to present the full scale of ideological positions exclusively in binary terms (ibid). Moreover, ideology as such, not just judicial ideology, has for a long time been primarily characterized "with a single dimension that spans from 'liberal' or

\footnotetext{
${ }^{8}$ In this vein our definition of judicial ideology corresponds to the following definition of ideology in Oxford English Dictionary, according to which ideology stands for »a systematic scheme of ideas, [...] relating to politics or society, or to the conduct of a class or group, and regarded as justifying actions, especially one that is held implicitly or adopted as a whole and maintained regardless of the course of events.«
} 
'left-wing' on one hand and 'conservative' or 'right-wing' on the other", so much so that Crawford et al. observe (Crawford, Brandt, Inbar, Chambers, Motyl, 2017) that it has provided "the basis for highly influential theories of ideology". Their advantages in terms of great predictive power and reduction of complexity have, however, been falsified by recent research which demonstrates that ideology is, as a matter of fact, multidimensional rather than unidimensional (ibid.). It is unobjectionable that already the mere terms liberal and conservative are themselves heterogeneous (Fischman, Law, 2009) and cannot be exhausted by a single ideological dimension (Everett, 2013). Also, the great predictive power of the unidimensional approach to ideology might work for the US Supreme Court, ${ }^{9}$ while it is much less applicable to other common law courts, let alone to the Kelsenian courts outside the US. Finally, as observed by Fischman and Law (2009), despite the prevalence of unidimensional ideological model, "there is no generally accepted methodology for assessing the dimensionality of an ideology space".

For these reasons, the present article does not follow the mainstream unidimensional model of ideology and rather endorses a multidimensional approach. In choosing the relevant dimensions, we follow the well established distinction in political science between economic and social ideologies. Crawford et al. (2017) explain social ideologies as those that "emphasize traditional moral and cultural issues (with conservatives and liberals favoring greater vs. lesser restriction, respectively, on personal freedom in moral and cultural domains)", and economic ideologies as those that "emphasize the role of the government in regulating the economy (with conservatives and liberals favoring lesser vs. greater roles for the government in regulating the economy, respectively)". Their definitions are based on Rokeach (1977) who understood the social ideology as a set of views and values regarding personal freedoms, and the economic ideology as the attitude towards equality, and on Maddox and Lillie (1984) who included the attitudes towards government intervention into the economic ideology. Empirical studies of peoples' ideological views have firmly established that a person may be, for example, liberal on the social and conservative on the economic dimension, and, more importantly, that social and economic ideologies cannot be reduced onto a single dimension (for example, Evans, Heath and Laljee, 1996; Layman and Carsey, 2002; Swedlow, 2008; Swedlow and Wickoff, 2009; Jost, Federico and Napier, 2009; Haidt, Graham and Joseph, 2009; Treier and Hillygus, 2009: Carmines, Ensley and Wagner, 2012; Klar, 2014; Jackson, 2014).

Based on this literature, we define the following two dimensions of judicial ideology:

* The economic dimension measures the judges' preferences on a continuum between the two opposite ends of unrestrained economic freedom of an individual and total state economic intervention. ${ }^{10}$

\footnotetext{
${ }^{9}$ Even so, $14 \%$ of cases at the US Supreme Court are said that cannot be explained by the unidemensional model (Fischman, Law, 2009).

${ }^{10}$ Authors that use multidimensional conceptions of ideology often define the economic dimension in terms of attitudes towards the distribution of income and wealth in a society, following Rokeach (1973). This aspect is integrated in our definition since any involuntary re-distribution of income and wealth requires state intervention in the economy.
} 
* The social dimension evaluates the judge's preferences for the rights of individuals or minorities against the collective interests of the various majorities in a society or against the rights of other individuals.

In addition to social and economic dimension, an important strand of literature in political science and psychology sees the attitudes towards the authority of the state and the preservation of social order as either another important dimension, or as an important distinction within the conservative ideology (Altmeyer, 1981; Thompson, Ellis and Wildavsky, 1990; Pratto et al., 1997; Janda, Berry and Goldman, 2002; Kay and Jost, 2003; Duckitt and Sibley, 2007; Schwartz et al., 2010; Swedlow 2008). We find this pertinent for the conceptualisation of judicial ideology as well. The courts, and constitutional courts in particular, often rule in cases in which the rights and freedoms of individuals had been violated not by other individuals or social groups but rather by the state. To capture this type of issues, we define a third dimension of judicial ideology:

* The authoritarian dimension is spread between the preferences to protect the rights and freedoms of the individuals on the one end and the protection of state interests (its organs and their monopoly of power) and the prevailing social order on the other end.

Our approach which defines the three ideological dimensions conceptually and ex-ante to empirical research is clearly distinct from how multidimensionality of ideology is understood and investigated in the existing literature on judicial ideology. Some authors have understood multidimensionality as taking ideologically inconsistent positions on different issues, for example a judge who votes conservatively on abortion cases may vote liberally on asylum cases (Fischman, Law, 2009). In our methodology this is not considered multidimensionality, but rather taking different positions along a single bipolar dimension (liberal/conservative). Others have combined the bipolar ideological dimension with judges' legal doctrine (legalism/pragmatism) or respect for selected legal principles (Fischman, Jacobi, 2016; Bailey, Maltzman 2008, 2011; Bailey, 2013). While these may be important factors contributing to judges' decisions, they do not constitute a separate ideological dimension. Finally, some authors have used factor analysis to derive distinct ideological dimensions from the data but often the dimensions so obtained are not comprehensive or easy to interpret. In the US, early studies by Schubert (1965, 1974) distinguished between economic and political liberalism. In Canada, Ostberg, Wetstein and Ducat (2002) found that the following factors best explain ideological disagreement among judges: communitarian/libertarian, fairness (in criminal procedures), and judicial activism/self-restraint. The two dimensions best explaining disagreement in the Brazilian Constitutional court were found to be the attitude towards cases related to the direct economic interests of the executive, and those related to the autonomy of states (Ferreira, Mueller, 2014). In the recent analysis of the Catalonian constitutional council, the pro-Spanish/pro-Catalan dimension was added to the conventionally defined conservative/liberal dimension (Dalla Pelegrina, Garoupa, 2018).

Overall, studies applying a genuinely multidimensional notion of ideology are very rare; we were not able to find any related to European constitutional courts. This speaks for novelty 
of our methodological approach. The next section explains how the three ideological dimensions were operationalized to be used in the empirical study of the ideology of the Slovenian Constitutional Court judges.

\section{Empirical Application of Multidimensional Judicial Ideology - The Case of the Slovenian Constitutional Court}

The Slovenian legal system (and most of legal theory) is based on seeing law as an objectivist positivist system. The role of courts is to determine the material truth based on objective legal norms. Any sign that judges have based their decision on their own beliefs is therefore seen as a deviation from the legal ideal and a reason for criticism. Such, in our view, unrealistic understanding of law and the role of judges leads to unrealistic expectations and consequently to constant disappointment with judicial decisions, which erodes their social legitimacy. Frequent allegations that the Constitutional Court is being "political" or "ideological" in its decisions reflect such misconceptions; of course, they also reveal the political and ideological positions of those making the allegations, especially when they come from the political arena. Such allegations, where the term ideology is used with a strong pejorative connotation, also motivated our critical research.

Nevertheless, with the establishment of a new, independent Constitutional Court in 1991 the legal grounds were laid for a gradual departure from the objectivist conception of law in the practice of Slovenian judiciary (and therefore gradually also in theory). The Constitutional Court was established as a notably different institution than the rest of the judiciary. It differs from the ordinary judiciary by its composition, duration of term, constitutional mandate and, most importantly, by its modus operandi. The judges are elected by a two stage procedure. In the first step, the President of the Republic nominates candidates for judges to the Parliament. There are no restrictions on who may propose candidates to the President, no limits on the number of candidates for one position, and no substantive limitations on the President's choice among the eligible candidates. In the second step, the Parliament elects the judges from among the candidates nominated by the President; a majority of all members of the Parliament is required for a judge to be appointed. The Court is composed of nine judges, elected for a fixed term of nine years. They rule in the cases of legality and constitutionality as well as in cases involving the protection of human rights. This makes the Slovenian Constitutional Court the ultimate arbiter of constitutionality and human rights protection. Since the Court has, traditionally, been composed also of the members of the legal academia and not solely of the established judicial class, its rulings follow a different judicial style, which approximates much closely the discursive conception of law. This is reaffirmed by the fact that, unlike the rest of the Slovenian judiciary, the Constitutional Court justices are authorized to write separately. They have, indeed, done so frequently in the past and have, by so doing, opened up a possibility for an empirical legal research in the ideological pedigree of the Slovenian Constitutional Court. 


\section{Source of information on ideology}

Unlike the common approach based only on coding of judges' votes, we look for expressions of ideological preferences in the text of the decision's justification as approved and published by the Court, and in the texts of judges' separate opinions. Full texts of all decisions and separate opinions, as well as information on voting by individual judges, are available at the Court's website.

We chose to read and hand-code the decisions and separate opinions rather than using an automated procedure because of the deeper insight into the reasoning of judges that we gain by reading their texts, which may be helpful for interpretation of results. Furthermore, we had expected the Court's style of writing to use a rather dry professional vocabulary avoiding ideologically-laden terms, and the frequency of words and phrases to reflect the issue at hand rather than ideological judgements, which could both render an automated procedure inaccurate. The downside of this, in our opinion correct methodological choice, is that the procedure of hand-coding is time consuming and cannot be applied on the Constitutional Court's case-law as a whole. We therefore had to limit our analysis to a sample of the Court's most salient decisions.

\section{Positions along ideological dimensions}

In our research on ideology in the Constitutional Court we use the three ideological dimensions (economic, social, and authoritarian) as defined in the previous section. To operationalize the dimensions for empirical research, we defined five ideological positions along each dimension that a court's decision or a judge's opinion can take.

Table 1: Ideological positions

\begin{tabular}{|l|l|l|l|}
\hline \multicolumn{1}{|c|}{$\begin{array}{c}\text { Ideological } \\
\text { dimension }\end{array}$} & \multicolumn{1}{|c|}{ Positions 1 and 2 } & \multicolumn{1}{c|}{ Position 3 } & Positions 4 and 5 \\
\hline Economic & $\begin{array}{l}\text { Strong/moderate } \\
\text { preference for state } \\
\text { intervention and } \\
\text { equality }\end{array}$ & $\begin{array}{l}\text { Balancing economic } \\
\text { freedom with } \\
\text { distributional concerns } \\
\text { and state intervention }\end{array}$ & $\begin{array}{l}\text { Moderate/strong } \\
\text { preference for } \\
\text { economic freedom }\end{array}$ \\
\hline Social & $\begin{array}{l}\text { Strong/moderate } \\
\text { preference for the } \\
\text { rights and freedoms of } \\
\text { individuals and } \\
\text { minority social groups }\end{array}$ & $\begin{array}{l}\text { Balancing individual } \\
\text { and minority freedoms } \\
\text { with majoritarian } \\
\text { values and collective } \\
\text { interest }\end{array}$ & $\begin{array}{l}\text { Moderate/strong } \\
\text { preference for } \\
\text { majoritarian social } \\
\text { values and collective } \\
\text { interest }\end{array}$ \\
\hline Authoritarian & $\begin{array}{l}\text { Strong/moderate } \\
\text { preference for } \\
\text { individual human } \\
\text { rights }\end{array}$ & $\begin{array}{l}\text { Balancing individual } \\
\text { rights with social order } \\
\text { and authority of the } \\
\text { state }\end{array}$ & $\begin{array}{l}\text { Moderate/strong } \\
\text { preference for authority } \\
\text { of the state and social } \\
\text { order }\end{array}$ \\
\hline
\end{tabular}

The mid-way position (Position 3) is defined as seeking balance between the rights of different individuals and groups (social dimension), or between individual rights and the state's authority and interest (authoritarian dimension), or between state intervention and 
free market principles (economic dimension). Other positions are intentionally constructed in such a way that positions left of the centre (Positions 1 and 2) in all dimensions corresponds to what is usually labelled as progressive or left-wing values, while positions right of the centre (Positions 4 and 5) correspond to conservative or right-wing values. However, this does not imply that a decision by the Constitutional Court which is coded as "left" in ideological terms will always be interpreted as having a "left-wing" bias in political terms. For example, consider a case where a journalist of a strongly right-wing political weekly allegedly trespassed the limits of the constitutional freedom of speech and injured the constitutional right to personal dignity of a left-wing politician. Had the Court ruled in favour of the freedom of speech, this would be coded as Position 1 or Position 2, i.e. as "left" on both the social and authoritarian dimension. However, in the political arena, the Court would very likely be accused of favouring the political right, that is, a right-wing newspaper against a left-wing politician. This example underlines that our methodology does not equate judicial ideology with a simplistic understanding of judges' political preferences or affiliations.

\section{Coding of Court decisions and separate opinions}

The first step in our analysis is coding of ideological positions of each Court decision in the sample. Coding proceeds in the following way. First we establish which ideological dimensions are relevant for a particular decision; that is, we consider whether the subject matter of the decision is related to the extent of state intervention or distributional issues, to the conflict between the rights of different individuals or social groups, or to the conflict between individual rights and the authority of the state. Then we establish the ideological position of the decision along all relevant dimensions. This is done by taking into consideration:

* the decision itself, for example, is the decision as such in favour of individual rights or in favour of majoritarian groups or state interests;

* the core arguments used in the explanation of the decision, i.e. is the decision justified by purely formal legal arguments or does the core justification include value judgements that can be interpreted in terms of our ideological dimensions and positions;

* auxiliary arguments (dicta) or issues discussed by the court, as well as the language of the justification; often, the text that is not central to the core argument of justification may reveal the values and ideological views behind the decision;

* the remedies required or instituted by the court, which may range from simply declaring a law or a decision by a lower level court as unconstitutional, to detailed instruction on what the courts must take into account in a new decision or how the law should be amended and interpreted in the meantime.

When the decision and its core argument can be interpreted as searching for balance between rights of different social groups, or between individual rights and state authority, or between economic freedom and regulation, the decision is coded as having Position 3 
on the relevant dimension. When the decision is not balanced in this sense, i.e. it can be interpreted as being ideologically "left" or "right" from the mid-way position, it has to be determined whether the decision reveals a strong or a moderate ideological position. This is determined by assessing the importance of value judgements for the core argument, the ideological positions revealed through auxiliary arguments and language, and the strength of the chosen remedy. Accordingly the decision is coded as having a moderate ideological position (Position 2 or 4 ) or a strong ideological position (Position 1 or 5).

Some examples may illustrate the reasoning to the reader. On the authoritarian dimension, the decision which established that the regulation of covert police operations did not sufficiently protect the right to privacy, but at the same allowed the regulation to remain in force until amended by the legislative (U-I-272/98, 2003), was coded 3 for trying to strike a balance between individual rights and the interest of the state for efficient investigations. Code 4 on the authoritarian dimension was assigned to the decision allowing questions about religion and nationality in the population census (U-I-92/01, 2002), for giving preference to the state's interest in collecting data over the individual right to privacy; code 4 was chosen over code 5 because the Court nevertheless emphasized the legal safeguards for data protection and the option to decline answering these questions. On the economic dimension, the decision upholding the law which demanded that private companies working with clients in areas with Hungarian and Italian minorities must have employees fluent in minority languages (U-I-218/04, 2006) was coded 1 for allowing a very strong intervention in the constitutional right to a free economic initiative. The same decision was coded 1 on the social dimension for giving a strong preference to very high standards of minority protection. Decisions regarding the freedom of speech were coded 4 on the social dimension when preference was given to protection of individual dignity and reputation (Up-462/02, 2004) and 2 when preference was given to the free expression of opinions (Up-422/02, 2005); codes 1 or 5 were not used in these cases as the Court never exclusively sided with either the freedom of speech nor the protection of injured individuals.

Once the decision has been coded, we use the same procedure for coding ideological positions of any separate opinion on the decision. Finally, because it is needed in the next step for scoring of judges' votes and separate opinion, we also determine the ideological position of a hypothetical counter-decision. A counter decision is the hypothetical opposite of the decision that was taken; for example, when the court declared a particular piece of legislation to be unconstitutional, or found that the constitutional rights of an individual were violated, a counter decision would have found the legislation not to be in conflict with the constitution or the rights not to be violated.

The methodology now applied was developed in a step-wise manner, by first testing it on a pilot sample of decisions and then improving the definitions of the dimensions and the reasoning applied in the coding of positions. Still there is obviously always a degree of subjectivity in any assessment of ideology. To limit the subjective bias and prevalence of a particular viewpoint, the research team is intentionally mixed in terms of professional backgrounds and career paths (including lawyers, political scientists and economists with experience from academia, public institutions and the private sector). 
Each decision is coded independently by at least two members of the research team. When their assessments differ, the issues are discussed at regular meetings of the entire team and the final assessment is reached in a consensual way. Assessments of decisions are documented and explained in writing on a unified template and will be made available for professional peer-review.

\section{Scoring and weighing of judges' ideological positions}

Once the decision and separate opinions (if any) are coded, the next step is to convert the codes into numerical values to allow for a quantitative analysis of judges ideological profiles and intensity of their preferences. We have developed a specific scoring and weighing procedure which takes into account the level of certainty about a judge's position on each separate decision.

First consider the simpler case of a Court's decision without any separate opinions. Here the only information we have about judges' ideological position is whether they voted in favour or against the decision. This information comes with a degree of uncertainty in the sense that voting for a decision does not necessarily mean that the judges' true ideological position fully corresponds with that of the decision. Following the well know median-voter theorem, the only thing we may be certain about a judge who voted for the decision is that her true ideological position is closer to the position of the decision than it is to the position of the hypothetical counter-decision. If it were not, the judge, staying faithful to her worldview, would have voted against the decision. The opposite, of course, holds for a judge who voted against the decision - his true position is closer to the position of the hypothetical counter-decision than it is to the position of the Court's decision.

We account for this type of uncertainty by distributing judges' ideological scores across adjacent position. For example, assume that the Court's decision was coded with Position 2. Judges who voted for the decision will score a point for Position 2, but also for the adjacent positions 1 and 3. Assume further that the hypothetical counter-decision was coded with Position 5. The judges who voted against the decision will score a point for the position of the counter-decision (Position 5) and for the adjacent Position 4.

Table 2: Example of scoring of judges' positions based on their votes

\begin{tabular}{|l|c|c|c|c|c|}
\hline & Position 1 & Position 2 & Position 3 & Position 4 & Position 5 \\
\hline DECISION 1 & & Decision & & & Counter-decision \\
\hline Judges voting in favour & 1 & 1 & 1 & & \\
\hline Judges voting against & & & & 1 & 1 \\
\hline DECISION 2 & & Decision & & Counter-decision & \\
\hline Judges voting in favour & 1 & 1 & 0.5 & & 1 \\
\hline Judges voting against & & & 0,5 & 1 & \\
\hline
\end{tabular}

A special case to this general rule is when a position is adjacent to both the position of the decision and that of the counter-decision. For example, if the decision was coded as Position 2, and the counter-decision with Position 4, Position 3 is adjacent to both. In such cases, judges who voted for and against the decision both score only half a point 
for Position 3. This again is based on the median-voter theorem; when the judges' true position is exactly in the middle of position of the two alternatives (the decision and the counter-decision), it is equally likely that the judge would vote for or against.

Now consider a decision to which some of the judges have written concurring or dissenting separate opinions. For judges who have written or joined a separate opinion, we assume that the position of the separate opinion reveals their true ideological position (in relation to the particular subject matter of the decision). To take into account the greater certainty about their true position, as compared with the judges who voted but did not write or join a separate opinion, judges who wrote a separate opinion are scored with two points for the position of the separate opinion, and none for any other position. For example, if the separate opinion was coded with Position 2 on the economic and Position 4 on the social dimension, the subscribing judges receive 2 points for positions "economic 2 " and "social 4". Another justification for scoring their position with 2 points rather than one is that judges are probably more likely to write a separate opinion when they have a strong preference for a particular position.

For judges who voted for or against the decision, but did not write a separate opinion, we apply the same general scoring rule as explained above but with a specific correction. When an adjacent position to a decision (counter-decision) is taken by a separate opinion, judges who voted in favour (against) the decision receive only half a point for this position. This is done so because if this had been their true position, they would have likely (but not necessarily) subscribed to the separate opinion. The lower weighing ( 0.5 point instead of 1 point) thus reflects the lesser probability that the judge's true position matches with the position of a separate opinion to which she did not subscribe.

Table 3: Example of scoring of judges' positions based on votes and separate opinions

\begin{tabular}{|c|c|c|c|c|c|}
\hline & Position 1 & Position 2 & Position 3 & Position 4 & Position 5 \\
\hline DECISION 1 & $\begin{array}{l}\text { Concurring } \\
\text { separate } \\
\text { opinion }\end{array}$ & Decision & & & $\begin{array}{l}\text { Counter-decision } \\
\text { and dissenting } \\
\text { separate opinion }\end{array}$ \\
\hline $\begin{array}{l}\text { Judges subscribing to } \\
\text { concurring opinion }\end{array}$ & 2 & & & & \\
\hline $\begin{array}{l}\text { Judges subscribing to } \\
\text { dissenting opinion }\end{array}$ & & & & & 2 \\
\hline Judges voting in favour & 0.5 & 1 & 1 & & \\
\hline Judges voting against & & & & 1 & 1 \\
\hline
\end{tabular}

\section{Sample of decisions used for testing the methodology}

In addition to the time-consuming coding procedure chosen for the analysis, there is a more substantive reason for using a sample of decisions rather than the whole jurisprudence. At this initial stage of our research, we first need to establish whether ideology, which undoubtedly plays a role in judicial decision-making, can be empirically detected and measured with the information available. Therefore we decided to create a sample of those 
decisions that are most likely to invoke and reveal the judges' collective and individual value judgements. Of course, the more complex, legally controversial and socially important is the issue presented to the Constitutional Court, the more room and need there will be for judges to resort to their own values and beliefs when deliberating on the issue. Accordingly our sample was chosen from a subset of decisions satisfying one or several of the following criteria:

* decisions that the Court itself has declared as important in its Annual Reports;

* decisions not taken unanimously, or with concurring or dissenting separate opinions;

* decisions on important legal and social issues that relate to our definition of the three ideological dimensions (e.g. violations of human rights, rights and freedoms of different individuals and minority social groups, political rights such as the right to referendum, economic freedom and state regulation, constitutional limits on the authority of the state);

* decisions of a precedential character or with important social consequences;

* decisions related to highly controversial issues in the political and public discussions.

The resulting sample, which we present below, is thus neither random nor representative of the whole body of Constitutional Court decisions; rather, it is compiled with the purpose of including important decisions that are likely to have been influenced by judges' ideological views.

The sample created for testing the methodology covers the period from 2002 to 2006 . We chose that period as one of the three periods during which the composition of the court has changed only marginally, i.e. two judges, Krisper Kramberger and Tratnik, did not vote on the first 14 decisions in the sample as they were appointed on May 25, 2002.

During this period, the Constitutional Court took a total of 860 decisions. All decisions were published with a number of descriptors indicating their subject matter. Using these descriptors, we have first eliminated from further consideration all decisions that were concerned solely with the delimitation of competences of different branches, levels or units of government, on assumption that ideological or value judgements could not have played a significant role in deliberations on such cases. This left us with 612 decisions, out of which we selected our sample. The sample includes in total 100 decisions, 20 per each year in the observed period, thus representing 16.3 per cent of all potentially relevant decisions.

The following figures compare the structure of the sample with the total of relevant decision with respect to their core subject matter, as derived from descriptors assigned to decisions by the Constitutional Court, and with respect to the level of disagreement between judges. Almost a third of all decision in the observed period was related to human right violations in law enforcement procedures, including court procedures. Although these decisions importantly reveal the Constitutional Court's position on the limits to state authority, we chose to under-represent this group of decisions in order to balance the sample. On the other hand, we over-represented decisions directly related to freedoms and rights of individuals and minority groups, which only take a small share of total decisions, but 
are important for understanding the Court's ideological position on the social dimension. Similarly we over-represented the decisions related to free economic initiative, due to their importance for revealing the economic ideology of judges.

Table 4: Structure of the sample with respect to the subject matter of decisions

\begin{tabular}{|l|l|c|c|c|c|c|}
\hline $\begin{array}{c}\text { Ideological } \\
\text { dimension }\end{array}$ & $\begin{array}{c}\text { Subject matter according } \\
\text { to content descriptors }\end{array}$ & $\begin{array}{c}\text { Number } \\
\text { in total }\end{array}$ & $\begin{array}{c}\text { Share } \\
\text { in total }\end{array}$ & $\begin{array}{c}\text { Number } \\
\text { in sample }\end{array}$ & $\begin{array}{c}\text { Share } \\
\text { in sample }\end{array}$ & $\begin{array}{c}\text { Sample / } \\
\text { Total }\end{array}$ \\
\hline Economic & Free economic initiative & 17 & 2.8 & 10 & 10.0 & 58.8 \\
& Property rights, restitution & 59 & 9.6 & 10 & 10.0 & 16.9 \\
& Public good, environment & 31 & 5.1 & 4 & 4.0 & 12.9 \\
& Taxation, public finance & 49 & 8.0 & 4 & 4.0 & 8.2 \\
& Social and workers' rights & 41 & 6.7 & 7 & 7.0 & 17.1 \\
\hline Social & Freedom of speech & 5 & 0.8 & 2 & 2.0 & 40.0 \\
& Right to privacy & 12 & 2.0 & 8 & 8.0 & 66.7 \\
& Children's and parents' rights & 5 & 0.8 & 1 & 1.0 & 20.0 \\
& Discrimination, minority rights & 12 & 2.0 & 9 & 9.0 & 75.0 \\
& Cultural and religious rights & 4 & 0.7 & 2 & 2.0 & 50.0 \\
\hline Authoritarian & Political rights, referenda & 55 & 9.0 & 13 & 13.0 & 23.6 \\
& Legality, political system & 100 & 16.3 & 10 & 10.0 & 10.0 \\
& Law enforcement, human rights & 222 & 36.3 & 20 & 20.0 & 9.0 \\
\hline Economic & All & 197 & 32.2 & 35 & 35.0 & 17.8 \\
Social & All & 38 & 6.2 & 22 & 22.0 & 57.9 \\
Authoritarian & All & 377 & 61.6 & 43 & 43.0 & 11.4 \\
\hline Total & All & 612 & & 100 & & 16.3 \\
\hline
\end{tabular}

Table 5: Structure of the sample with respect to disagreement among judges

\begin{tabular}{|l|c|c|c|c|}
\hline & $\begin{array}{c}\text { Number } \\
\text { in total }\end{array}$ & $\begin{array}{c}\text { Share } \\
\text { in total }\end{array}$ & $\begin{array}{c}\text { Number } \\
\text { in sample }\end{array}$ & $\begin{array}{c}\text { Share } \\
\text { in sample }\end{array}$ \\
\hline Unanimous decisions & 446 & 76.1 & 59 & 59.0 \\
\hline $\begin{array}{l}\text { Decisions with at least one judge voting } \\
\text { against at least a part of the decision }\end{array}$ & 146 & 23.9 & 41 & 41.0 \\
\hline Decisions with a separate opinion & 80 & 13.1 & 39 & 39.0 \\
\hline
\end{tabular}

Almost a quarter of all decisions in the observed period were not taken by unanimity. One or more judges have written separate opinions on 80 decisions (13.1 per cent of all). Since we expect that ideological differences may be one of the factors leading the judges to vote against the decision and to write concurring or dissenting separate opinions, we deliberately over-represented non-unanimous decisions and decisions with separate opinions in our sample.

As already explained, the sample was created with the intention to pick up the decision where the ideological positions of the Court and individual judges are most likely to 
have played a role and to be revealed through voting on the decision, decision's written justification and separate opinions. Therefore the sample was created following a set of pre-defined criteria and is thus not fully representative of the whole body of jurisprudence in terms of subject matters or unanimity, but, as the discussion above demonstrated, all deviations can be justified by the purpose of selecting the most ideology-prone decisions.

\section{Ideological profiles of the Court and judges}

In the final step, we applied the coding and scoring procedure for ideological position of the Court and individual judges to the decisions in our sample. The result of this procedure is a database which provides information, for each decision in the sample, on the ideological positions of the Constitutional Court along all relevant dimensions, and on positions taken by each voting judge, scored as described. In addition to the ideological positions, we also determine for each decision and separate opinion to what extent it refers to international and foreign law and judicial practice (e.g. international conventions, EU directives, decisions by the ECtHR or foreign constitutional courts), and whether and to what extent it is in line with the government's and the parliament's position on the case. Namely, when deciding on constitutionality of laws and bylaws, the Constitutional Court invites the parliament and the government to submit their opinions and summarizes them in the explanation of the decision. Data on what we call the "international dimension" and the "pro-government" orientation of Courts' decisions are also entered into the database. Two important issues emerged during the coding procedure. First, a single decision of the Court may involve several points which may relate to distinct subject matters. For example, a decision on the constitutionality of the population census considered the permissibility of questions on religion and nationality, as well as the permissibility of using the data collected through the census for purposes of administrative procedures. In such cases, we coded a decision on each subject matter separately. In some cases, we also coded the preliminary decision whether to suspend the contested legislation or court judgement until the decision of the Constitutional Court is taken, when the justification of this pre-decision included value judgements or was not taken unanimously. For this reason, the final data base includes 108 entries based on 100 analysed decisions. In the following, the term "decision" thus relates to all entries in the sample regardless of whether they relate to the entire Court's decision or a part thereof.

The second issue we encountered during the analysis was that some decisions could not be coded on the dimension which seemed most closely related to their subject matter. For example, decisions on tax matters or property rights were expected to include the economic dimension, but often they were based exclusively on procedural or legality arguments (i.e. retroactivity of the law). In such cases, the seemingly most relevant ideological dimension for the subject matter was not coded. Thus, we were able to determine the ideological position along the authoritarian dimension for most (105) entries in the sample, while the social dimension was assessed for 52 decisions and the economic dimension for 38 decisions. The following analysis demonstrates how the database may be used to estimate ideological profiles and ideal points of the Court and individual judges. 
From the data base of coded decisions, we estimated the ideological profile of the Constitutional Court by calculating, for each dimension, the relative frequencies of the number of times a Court's decision was assigned a particular position along that dimension. Relative frequencies may be interpreted as an indicator of the intensity of preferences for a particular position. Ideal points of the Court on each dimension are calculated as the average value of the positions (from 1 to 5) taken by Court on all decisions in the sample where that dimension was identified.

Figure 1 shows the ideological profile and ideal points of the Court. We can see that the Court, in the ideologically important decisions taken in the observed period, had a strong preference for social liberalism, and a weaker preference for political liberalism. In other words, the Court more strongly protected the rights and liberties of an individual against other individuals and social groups than it did protect individual rights against the authority of the state. On the other hand, the profile for the economic dimension is rather flat, implying that ideological preferences on this dimension were not very strong, or, as is actually the case, that the court took very different positions in individual decisions.

Figure 1: Ideological profile and ideal points of the Constitutional Court

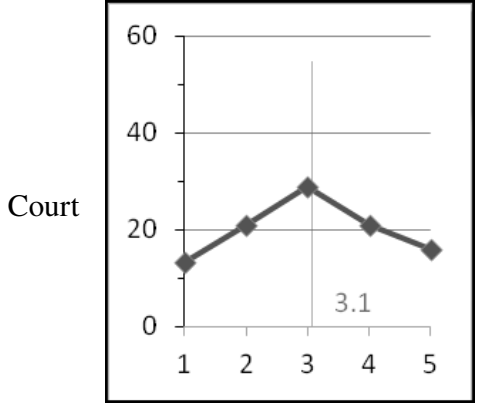

Economic dimension

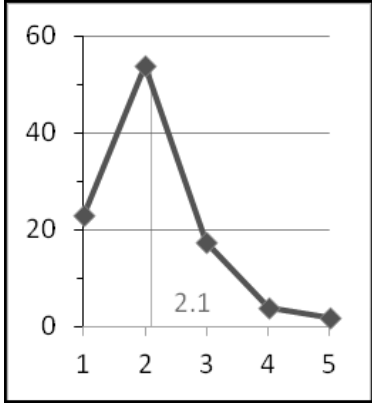

Social dimension

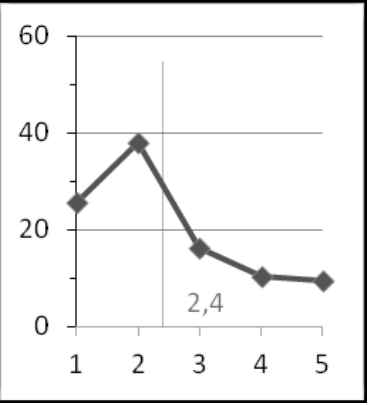

Authoritarian dimension

Note: The horizontal axis plots ideological positions along the dimension, the vertical axis measures the intensity of preference (relative frequencies) for each position. The red vertical line and the number present the ideological ideal points.

Number of observations - economic dimension: 38 decisions, social: 52, authoritarian: 105.

For individual judges, their ideological profiles are obtained by calculating the shares of total scores received by the judge for each position along a given dimension. In so doing the ideological profiles take into account the higher weights assigned to separate opinions, and lower weights assigned for the position of the separate opinion for judges who did not write or subscribe to an opinion on that particular case. We do not show profiles for individual judges here, but, with only two exceptions on the economic dimension, they are all single-peaked. This implies that the further away a given ideological position is from the judge's preferred position, the less likely it is that the judge will vote (or write an opinion) in line with that position. 
Judges' ideal points are calculated for each dimension as the weighted average of points received by the judge for each possible position on that dimension. ${ }^{11}$ Table 6 shows the ideal points of all nine judges, the median of their ideal points, and the ideal point of the Court for all three dimensions. It also reports the standard deviation of scores for positions on individual decisions. These standard deviations may be interpreted as a measure of dispersion of ideological preferences over all positions in a dimension.

Table 6: Judges' ideal points

\begin{tabular}{|l|c|c|c|c|c|c|}
\hline \multirow{2}{*}{\multicolumn{1}{c|}{ Judge }} & \multicolumn{2}{|c|}{ Economic dimension } & \multicolumn{2}{c|}{ Social dimension } & \multicolumn{2}{c|}{ Authoritarian dimension } \\
\cline { 2 - 7 } & IP & SD & IP & SD & IP & SD \\
\hline Čebulj & 2.9 & 1.2 & 2.3 & 1.0 & 2.5 & 1.2 \\
Fišer & 2.9 & 1.1 & 2.2 & 0.8 & 2.4 & 1.1 \\
Janko & 3.0 & 1.1 & 2.2 & 0.8 & 2.6 & 1.1 \\
Krisper-K. & 2.9 & 1.2 & 2.2 & 0.8 & 2.6 & 1.2 \\
Modrijan & 3.0 & 1.1 & 2.3 & 1.0 & 2.6 & 1.2 \\
Ribičič & 3.0 & 1.1 & 2.1 & 0.8 & 2.3 & 1.0 \\
Škrk & 2.9 & 1.1 & 2.0 & 0.7 & 2.5 & 1.1 \\
Tratnik & 2.8 & 1.1 & 2.2 & 0.9 & 2.5 & 1.1 \\
Wedam-L. & 3.1 & 1.1 & 2.1 & 0.8 & 2.3 & 1.0 \\
The Court & 3.1 & 1.3 & 2.1 & 0.9 & 2.4 & 1.2 \\
Median of judges & 2.9 & & 2.2 & & 2.5 & \\
\hline
\end{tabular}

Note: $I P=$ ideal point; $S D=$ standard deviation of scores for all decisions.

Number of observations - for the Court as in Figure 1; for individual judges, there are 32-38 observations for the economic dimension, 41-51 for the social dimension, and 92-104 for the authoritarian one. For two judges who were appointed later, there are 27 and 31 observations for the economic dimension, 37 and 45 for the social one, and 80 and 83 for the authoritarian dimension.

Ideal points of judges, calculated on the whole sample and reported in Table 6, may conceal the actual extent of ideological diversity among judges. More than a half of decisions in the sample were taken unanimously, and in unanimous decisions all judges receive the same position and scores, unless they write a concurring separate opinion or do not vote on the decision (i.e. being absent or excluded due to a conflict of interest). To take this into account, we recalculated ideal points of judges and the Court separately for unanimous and contested decision. Contested decisions are defined as those where at least one judge voted against the entire decision or a part of it. Table 7 reports the results for the social and the authoritarian dimension; the economic dimension was excluded due to a lower number of observations.

\footnotetext{
${ }^{11}$ For example, if a judge received 10 points for positions 1 and 2, 20 points for positions 3,15 points for position 4 , and 5 points for position 5 , his or her ideal point is 2.9 (i.e. $10 * 1+10 * 2+20 * 3+15 * 4+5 * 5=175$, divided by the total points received for the dimension, which in this case is $10+10+20+15+5=60$ ).
} 
The distances among judges' positions are, as expected, wider in contested decisions than in the whole sample. Moreover, ideal points of all judges and the Court in contested decisions are less liberal (closer to the centre) than in unanimous decisions. Overall, these results suggest that when judges do reach unanimity, they do so on a rather liberal social and political position, and that dissent occurs when their positions on the case are considerably less liberal than the ideal position of unanimous decisions.

Table 7: Ideal points in contested and unanimous decision

\begin{tabular}{|l|c|c|c|c|c|c|}
\hline & \multicolumn{3}{|c|}{ Social dimension } & \multicolumn{3}{c|}{ Authoritarian dimension } \\
\hline \multicolumn{1}{|c|}{ Judge } & $\begin{array}{c}\text { All } \\
\text { decisions }\end{array}$ & $\begin{array}{c}\text { Unanimous } \\
\text { decision }\end{array}$ & $\begin{array}{c}\text { Contested } \\
\text { decisions }\end{array}$ & $\begin{array}{c}\text { All } \\
\text { decisions }\end{array}$ & $\begin{array}{c}\text { Unanimous } \\
\text { decision }\end{array}$ & $\begin{array}{c}\text { Contested } \\
\text { decisions }\end{array}$ \\
\hline Čebulj & 2.3 & 1.9 & 2.9 & 2.5 & 2.2 & 2.9 \\
Fišer & 2.2 & 1.9 & 2.7 & 2.4 & 2.2 & 2.7 \\
Janko & 2.2 & 1.9 & 2.6 & 2.6 & 2.2 & 3.0 \\
Krisper-K. & 2.2 & 2.0 & 2.6 & 2.6 & 2.3 & 3.1 \\
Modrijan & 2.3 & 1.9 & 2.9 & 2.6 & 2.2 & 3.1 \\
Ribičič & 2.1 & 1.8 & 2.5 & 2.3 & 2.2 & 2.4 \\
Škrk & 2.0 & 1.8 & 2.4 & 2.5 & 2.3 & 2.9 \\
Tratnik & 2.2 & 1.9 & 2.8 & 2.5 & 2.3 & 2.8 \\
Wedam-L. & 2.1 & 1.9 & 2.4 & 2.3 & 2.1 & 2.6 \\
The Court & 2.1 & 1.5 & 3.0 & 2.4 & 1.9 & 2.6 \\
Median of judges & 2.2 & 1.9 & 2.6 & 2.5 & 2.2 & 2.9 \\
\hline
\end{tabular}

Note: Number of observations for all decision is as reported in Table 1. For unanimous decisions, it ranges from 29 to 33 on the social dimension and from 55 to 59 on the authoritarian. For contested decisions, the number of observations is between 12 and 19 on the social dimension and between 37 and 46 on the authoritarian. For the 2 judges that joined the Court later (Krisper-Kramberger and Tratnik), there are 25 and 29 observations for unanimous decisions on the social dimension, and 48 and 51 on the authoritarian. For contested decisions there are 14 and 16 observations for these two judges on the social dimension and 32 on the authoritarian.

\section{Conclusion and further research}

The paper presented a conceptual framework and an empirical methodology of an ongoing research on the role of ideology in the decisions of the Slovenian Constitution Court. The literature review demonstrated that research on judicial ideology in the courts of European countries and international courts is still rare. It was proposed that this lack of research on judicial ideology can be explained by conceptual, methodological and empirical challenges. While the very concept of judicial ideology evades an easy definition, it is the objectivist conception of law, which largely prevails among legal scholars and practitioners in the legal systems based on civil law, as opposed to common law systems, that has contributed to the negative attitude towards judicial dissent and the prohibition of dissenting opinions, which consequently seriously constrains the expression, the observation and hence the analysis of judicial ideology. 
The research of the Slovenian Constitutional Court benefits from public availability of all court decisions, including information on voting by individual judges, as well as from publication of all concurring and dissenting separate opinions. The conceptual framework of the ongoing research is based on a multidimensional conception of ideology which is empirically operationalised along the economic, social and authoritarian dimension with five possible ideological positions on each dimension. By applying the methodology to a sample of Court's decisions, it was shown that the methodology developed in the paper is able to account for ideological differences between judges. This confirms that (judges') ideology is a complex multidimensional set of values and convictions that cannot be reduced to simply equating ideology with (possible) political affiliations.

The empirical part of the article was intentionally limited to testing the validity and usefulness of the multidimensional approach to judicial ideology. Nevertheless it also indicated some interesting directions for further research. The identified differences in ideological positions between unanimous and contested decisions suggest that further comparisons, i.e. between pro and counter government decisions, or between decisions with and without references to international law, or between types of cases, would be interesting. They might shed more light on factors that contribute to consent and dissent within the Court. The different and not too strong correlations between judges' positions on individual cases also merit further investigation of possible groupings or voting coalitions within the court, e.g. by using methods such as clustering of judges based on their ideological positions. Furthermore, comparisons of ideal points between different periods or between different compositions of the Court could provide information about changes of ideological preference through time. An effort could also be made to try to explain the established ideological differences between judges by their professional background, political involvement and other characteristics.

\section{Acknowledgments}

The research presented in this article was co-financed by the Slovenian Research Agency, Grant number J5-8240 (A). The authors gratefully acknowledge the contribution of the research team (Katarina Vatovec, Jernej Letnar Černič, Ana Jevšek Pezdir, Snežana Šušteršič) to the on-going research project and this paper. They thank, alphabetically, Mark Baskin, Valentina Dimitrova Grajžl, Nuno Garoupa, Monika Glavina, Peter Grajžl, Richard Michael Kirkham and Aljaž Kunčič for their comments on earlier versions of the paper or presentations of the research. 


\section{References}

Alarie, R. D. B., Green, J. A. (2008). Should They All Just Get Along? Judicial Ideology, Collegiality, and Appointments to the Supreme Court of Canada. University of New Brunswick Law Journal, 53, 73-91.

Alexander, S. G. (2002). Comparing the Two Legal Realisms - American and Scandinavian. The American Journal of Comparative Law, 50, 131-174.

Alexy, R., Adler, R., MacCormick, N. (2009). Theory of Legal Argumentation. Oxford: Oxford University Press.

Altemeyer, R. (1981). Right-Wing Authoritarianism. Winnipeg, Canada: University of Manitoba Press.

Azizi, J. (2011). Unveiling the EU Courts' Internal Decision-Making Process: A Case for Dissenting Opinions? ERA Forum, 12, 49-68.

Bailey, A. M. (2016). Measuring Ideology on the Courts. In Howard, R. M., Randazzo K.A. (eds.). Routledge Handbook of Judicial Behavior. New York: Routledge.

Bailey, A. M., Maltzman, F. (2008). Does Legal Doctrine Matter: Unpacking Law and Policy Preferences on the U.S. Supreme Court. American Political Science Review, 102, 369-384.

Bailey, A. M., Maltzman, F. (2011). The Constrained Court: Law, Politics, and the Decisions Justices Make. Princeton: Princeton University Press.

Bailey, A. M. (2013). Is Today's Court the Most Conservative in Sixty Years? Challenges and Opportunities in Measuring Judicial Preferences. Journal of Politics, 75, 821-834.

Bjarup, J. (2005). The Philosophy of Scandinavian Legal Realism. Ratio Juris, 18(1), $1-15$.

Blanes i Vidal, J., Leaver, C. (2011). Are Tenured Judges Insulated from Political Pressure? Journal of Public Economics, 95, 570-586.

Blanes i Vidal, J., Leaver C. (2013). Social Interactions and the Content of Legal Opinions. Journal of Law, Economics and Organization, 29, 78-114.

Bricker, B. (2017). Breaking the Principle of Secrecy: An Examination of Judicial Dissent in the European Constitutional Courts. Law \& Policy, 39(2), 170-191.

Brouard, S. (2010). The Study of Judicial Politics in France. French Politics, 8, 72-76.

Carmines, E. G., Ensley, M.J., Wagner, M.W. (2012). Political Ideology in American Politics: One, Two, or None? The Forum, 10(4), 1-18.

Carrubba, J. C., Gabel, M., Hankla, C. (2008). Judicial Behavior under Political Constraints: Evidence from the European Court of Justice. American Political Science Review, 102(4), 435-452.

Crawford, T. J., Brandt, M. J., Inbar, Y., Chambers, R. J., Motyl, M. (2017). Social and Economic Ideologies Differentially Predict Prejudice across the Political Spectrum, but Social Issues are Most Divisive. Journal of Personality and Social Psychology, 112(3), 383-412.

Dalla Pellegrina, L., Garoupa, N., Gomez-Pomar, F. (2014). Estimating Judicial Ideal Points in the Spanish Supreme Court: The Case of Administrative Review. International Review of Law and Economics, 52(C), 16-28. 
Dalla Pellegrina, L., De Mot, J., Faure, M., Garoupa, N. (2017). Litigating Federalism: An Empirical Analysis of the Belgian Constitutional Court Decisions. European Constitutional Law Review, 13(2), 305-346.

Dalla Pelegrina, L., Garoupa, N. (2018). Estimating Judicial Ideal Points in a Bidimensional Court. Paper presented at the Conference on Empirical Legal Studies in Europe, Leuven.

Duckitt, J., Sibley, C. G. (2007). Right wing authoritarianism, social dominance orientation and the dimensions of generalized prejudice. European Journal of Personality, 21(2), 113-130.

Dunoff, L. J., Pollack, M. A. (2015). International Judicial Dissent: Causes and Consequences. Retrieved June 10, 2019, from https://eustudies.org/conference/papers/download/84, 1-41.

Dworkin, R. Law's Empire. (1986). Cambridge: Harvard University Press.

Dworkin, R. Justice for Hedgehogs. (2013). Cambridge: Harvard University Press.

Epstein, L., Landes, W., Posner, R. A. (2013). The Behavior of Federal Judges: A Theoretical and Empirical Study of Rational Choice. Cambridge: Harvard University Press.

Eisenberg, T., Fisher, T., Rosen-Zvi, I. (2013). Group Decision Making on Appellate Panels: Presiding Justice and Opinion Justice Influence in the Israel Supreme Court. Psychology, Public Policy, and Law, 19, 282-296.

Espinosa, R. (2013). Constitutional Judicial Behavior: Exploring the Determinants of the Decisions of the French Constitutional Court. Review of Law and Economics, 13(2), 1-37. Evans, G., Heath, A., Lalljee, M. (1996). Measuring Left-Right and LibertarianAuthoriarian Values in the British Electorate. British Journal of Sociology, 47(1), 93-112. Everett, A. C. J. (2013). The 12 Item Social and Economic Conservatism Scale (SECS). PLoS ONE, 8(12), 1-11.

Ferreira, P. F. A. N., Muller, B. (2014). How Judges Think in the Brazilian Supreme Court: Estimating ideal points and identifying dimensions. Economia, 15, 275-293.

Fiorino, N., Padovano, F., Sgarra, G. (2007). The Determinants of Judicial Independence: Evidence from the Italian Constitutional Court (1956-2002). Journal of Institutional and Theoretical Economics, 163, 683-705.

Fischman, B. J., Law, D. S. (2009). What is Judicial Ideology, and How do we Measure it? Washington Journal of Law and Policy, 29, 133-213.

Fischman, B. J., Jacobi, T. (2016). The Second Dimension of the Supreme Court. William \& Mary Law Review, 75, 1671-1715.

Franck, R. (2009). Judicial Independence under a Divided Polity: A Study of the Rulings of the French Constitutional Court, 1959-2006. Journal of Law, Economics and Organization, 25, 262-284.

Garoupa, N. (2011). "Empirical Legal Studies and Constitutional Courts". The Indiana Journal of Constitutional Law, 5, 26-54.

Garoupa, N., Gómez-Pomar, F., Grembi, V. (2013). Judging Politically: An Empirical Analysis of Constitutional Review Voting in the Spanish Constitutional Court. Journal of Law, Economics and Organization, 29, 513-534. 
Garoupa, N., Grembi, V. (2015). Judicial Review and Political Partisanship: Moving from Consensual to Majoritarian Democracy. International Review of Law and Economics, 43, 32-45.

Garoupa, N. (2016). “Constitutional Review.” Retrieved June 10, 2019, from: economix.fr/pdf/workshops/2016_3rd_law_eco/NGaroupa.pdf.

Ginsburg, R. B. (2010). The Role of Dissenting Opinions. Minnesota Law Review, 95(1), $1-8$.

Ginsburg, T. (2011). Building Reputation in Constitutional Courts: Political and Judicial Audiences. Arizona Journal of International and Comparative Law, 28(3), 539-568.

Grendstad, G., Shaffer, W. R., Waltenburg, E. N. (2015). Policy Making in an Independent Judiciary: The Norwegian Supreme Court. Colchester: ECPR Press Monographs.

Habermas, J. (1996). Between Facts and Norms, Contributions to a Discourse Theory of Law and Democracy. Cambridge: MIT Press.

Haidt, J., Graham, J., Craig, J. (2009). Above and Below Left-Right: Ideological Narratives and Moral Foundations. Psychological Inquiry, 20, 110-119.

Hanretty, C. (2012a). The Decisions and Ideal Points of British Law Lords. British Journal of Political Science, 43, 703-716.

Hanretty, C. (2012b). Dissent in Iberia: The Ideal Points of Justices on the Spanish and Portuguese Constitutional Tribunals. European Journal of Political Research, 51, 671-692.

Hanretty, C. (2014). The Bulgarian Constitutional Court as an Additional Legislative Chamber. East European Politics and Societies, 28, 540-558.

Hart, H. L. A. (1961). The Concept of Law. Oxford: Clarendon Press.

Hönnige, C. (2009). The Electoral Connection: How the Pivotal Judge Affects Oppositional Success in European Constitutional Courts. West European Politics, 35, 963-984.

Iaryczower, M., Katz, G. (2016). More than Politics: Ability and Ideology in the British Appellate Committee. Journal of Law, Economics and Organization, 32, 61-93.

Jackson, N. (2014). The Dimensional Structure of Symbolic Ideology: An Experiment on Liberal-Conservative Self-Placements. Retrieved June 10 from http://www.tessexperiments.org/data/jackson002.html.

Jost, J. T., Federico, C. M., Napier, J. L. (2009). Political Ideology: Its Structure, Functions, and Elective Affinities. Annual Review of Psychology, 60, 307-337.

Kantorowicz, J., Garoupa, N. (2016). An Empirical Analysis of Constitutional Review Voting in the Polish Constitutional Tribunal 2003-2013. Constitutional Political Economy, 27, 66-92.

Kay, A. C., Jost, T. J. (2003). Complementary justice: Effects of 'poor but happy' and 'poor but honest' stereotype exemplars on system justification and implicit activation of the justice motive. Journal of Personality and Social Psychology, 85(5), 823-837.

Kelsen, H. (1967). Pure Theory of Law. Berkeley: University of California Press.

Klar, S. (2014). A Multidimensional Study of Ideological Preferences and Priorities among the American Public. Public Opinion Quarterly, 78(1), 334-359.

Klein, D., Lindquist, S. A. (2012). Consensus, Disorder, and Ideology on the Supreme Court. Journal of Empirical Legal Studies, 9(1), 129-148. 
Kozinski, A. (1993). What I Ate for Breakfast and Other Mysteries of Judicial Decision Making. Loyola Los Angeles Law Review, 26, 993-1000.

Kumar, N. P., Smyth, R. (2007). What Explains Dissent on the High Court of Australia? An Empirical Assessment Using a Cointegration and Error Correction Approach. (2007). Journal of Empirical Legal Studies, 4, 401-425.

Layman, G. C., Carsey, T. M. (2002). Party Polarization and Party Structuring of Policy Attitudes: A Comparison of Three NES Panel Studies. Political Behavior, 24, 199-236.

Leiter, B. (2010). Legal Formalism and Legal Realism: What is the Issue? University of Chicago Public Law \& Legal Theory Working Paper, 320, 1-31.

Maddox, W. S., Lilie, S. A. (1984). Beyond Liberal and Conservative: Reassessing the Political Spectrum. Washington, D.C.: Cato Institute.

Malecki, M. (2009). Judicial Behavior behind Mask and Shield: Modelling the European Court of Justice. Paper prepared for the 2009 annual meeting of the American Political Science Association.

Malecki, M. (2012). Do ECJ judges all speak with the same voice? Evidence of divergent preferences from the judgments of chambers. Journal of European Public Policy, 19(1), 59-75.

MacCormick, N. (2007). Institutions of Law: An Essay in Legal Theory. Oxford: Oxford University Press.

Mannheim, K. (1966). Ideology and Utopia: an Introduction to the Sociology of Knowledge. London: Routledge.

Ostberg, C. L., Wetstein, M. E., Ducat, C. L. (2002). Attitudinal Dimensions of Supreme Court Decision Making in Canada: The Lamer Court, 1991-1995. Political Research Quarterly, 55, 242-49.

Ostberg, C. L., Wetstein, M. E. (2007). Attitudinal Decision Making in the Supreme Court of Canada. Vancouver: University of British Columbia Press.

Padovano, F. (2009). The Time-Varying Independence of Italian Peak Judicial Institutions. Constitutional Political Economy, 20, 230-250.

Pavčnik, M. (2013). Argumentacija v pravu. Ljubljana: GV Založba.

Pratto, F., Sidanius, J., Stallworth, L. M., Malle, B. F. (1994). Social dominance orientation: A personality variable predicting social and political attitudes. Journal of Personality and Social Psychology, 67, 741.

Posner, E., de Figueiredo, M. (2004). Is the International Court of Justice Biased? John M. Olin Program in Law and Economics Working Paper, 234, 1-44.

Raffaeli, R. (2012). Study of Dissenting Opinions in the Supreme Courts of the Member States. Brussels: European Parliament.

Raz, J. (2009). The Authority of Law: Essays on Law and Morality. Oxford: Oxford University Press.

Robertson, D. (1982). "Judicial Ideology in the House of Lords: A Jurimetic Analysis". British Journal of Political Science, 12, 1-25.

Robertson, D. (2010). The Judge as Political Theorist. Princeton: Princeton University Press.

Rokeach, M. (1973). The Nature of Human Values. New York: Free Press. 
Rosenfeld, M. (2006). Comparing constitutional review by the European Court of Justice and the U.S. Supreme Court. International Journal of Constitutional Law, 4(4), 618-651. Santoni, M, Zucchini, F. (2003). Legislative Output and the Constitutional Court in Italy. Constitutional Political Economy, 17, 165-187.

Schubert, A. G. (1965). The Judicial Mind: the Attitudes and Ideologies of Supreme Court Justices, 1946-1963. Evanston: Northwestern University Press.

Schwartz, S. H., Caprara, G. V., Vecchione, M. (2010). Basic personal values, core political values, and voting: A longitudinal analysis. Political Psychology, 31, 421-452.

Shachar, Y, Gross, M., Harris, R. (1997). Anatomy of Discourse and Dissent in the Supreme Court - Quantitative Analyses. Tel Aviv University Law Review, 20, 749-795.

Songer, R. D., Johnson, S. W., Ostberg, C. L., Wetstein, M. E. (2012). Law, Ideology and Collegiality: Judicial Behaviour in the Supreme Court of Canada. Montreal: McGillQueens University Press.

Spitzer, M., Talley, E. (2013). Left, Right and Center: Strategic Information Acquisition and Diversity in Judicial Panels. The Journal of Law, Economics, and Organization, 29(3), 638-680.

Swedlow, B. (2008). Beyond Liberal and Conservative: Two-dimensional Conceptions of Ideology and the Structure of Political Attitudes and Values. Journal of Political Ideologies, $13,157-180$.

Swedlow, B., Wyckoff, M. L. (2009). Value Preferences and Ideological Structuring of Attitudes in American Public Opinion. American Politics Research, 37, 1048-1087.

Tamanaha, Z. B. (2009). Beyond the Realist-Formalist Divide: The Role of Politics in Judging. Princeton: Princeton University Press.

Thompson, M., Ellis, R., Wildavsky, A. (1990). Cultural Theory. Boulder, CO: Westview Press.

Toplak, J. (2016). Judicial Behavior on the European Court of Human Rights. ECPR General Conference, Prague.

Treier, S., Hillygus, D. S. (2009). The Nature of Political Ideology in the Contemporary Electorate. Public Opinion Quarterly, 73, 679-703.

Vanberg, G. (2005). The Politics of Constitutional Review in Germany. Cambridge: Cambridge University Press.

Voeten, E. (2008). The Impartiality of International Judges: Evidence from the European Court of Human Rights. American Political Science Review, 102(4), 417-433.

Volcansek, L. M. (2000). Constitutional Politics in Italy. Basingstoke: Palgrave Macmillan Press.

Weinshall-Margel, K. (2011). Attitudinal and Neo-Institutional Models of Supreme Court Decision Making: An Empirical and Comparative Perspective from Israel. Journal of Empirical Legal Studies, 8, 556-586.

Wetstein, E. M., Ostberg, C. L., Songer, D., Johnson, S. (2009). Ideological Consistency and Attitudinal Conflict: A Comparison of the U.S. and Canadian Supreme Courts. Comparative Political Studies, 42, 763-792. 